\title{
Mating systems in caridean shrimp (Decapoda: Caridea) and their evolutionary consequences for sexual dimorphism and reproductive biology
}

\author{
Sistemas de apareamiento en camarones carideos (Decapoda: Caridea) y sus conse- \\ cuencias evolutivas en el dimorfismo sexual y biología reproductiva
}

\author{
CRISTIÁN CORREA ${ }^{1} \&$ MARTIN THIEL $^{2}$
}

Facultad de Ciencias del Mar, Universidad Católica del Norte, Larrondo 1281, Coquimbo, Chile; email: correa@chile.com ${ }^{1}$, (corresponding author) thiel@ucn.cl2

\begin{abstract}
In this paper we review functional and evolutionary relationships among mating systems of caridean shrimp and specific traits such as general biology/ecology, sexual systems, behavior and morphology. Four mating systems are described based on reports from available literature, and a fifth system is recognized but published information is insufficient to describe it in detail. 'Monogamy' occurs in many species inhabiting monopolizable refuges or hosts, especially when environmental conditions restrict the probability of intraspecific interactions. In contrast, free-living species experience higher encounter rates and males can dominate or search. In 'neighborhoods of dominance' mating systems, large males have higher reproductive success since they perform better in fights for receptive females. In 'pure searching' mating systems, small and agile males do better because they search more efficiently for mates within the population. The fourth mating system is 'search \& attend' occurring in solitary symbionts, which experience variable ecological and demographic environments: depending on environmental conditions and ontogenetic stages it may either be profitable for males to search or to attend hosts with sexually attractive females. Sexual systems of caridean shrimp are characterized by their high diversity and intraspecific plasticity, including gonochorism and different forms of protandric or simultaneous hermaphroditism. The identified mating systems partially explained this diversity: In monogamous species, low encounter rates and lack of sexual dimorphism favors simultaneous hermaphroditism but gonochory usually occurs among these species probably because mates are not strictly faithful. Species with neighborhoods of dominance mating are gonochoristic because both sexes benefit from being large. Pure searching species have a wide opportunity for the evolution of protandry since small males benefit while the opposite is true for females. In species with search \& attend the situation is variable, and only some males benefit by acquiring large size while others do better by searching or changing sex. In contrast to other crustaceans free-living shrimp do not exhibit precopulatory mate guarding and they are relatively unaggressive. The characteristic and efficient escape behavior of shrimp using their contractile abdomen might be one important trait that has constrained the evolution of such behaviors. Our review indicates that the mating systems of caridean shrimp depend both on environmental and on biological characteristics.
\end{abstract}

Key words: Caridea, mating behavior, mating system, sexual dimorphism, sexual system.

\section{RESUMEN}

En este articulo revisamos relaciones funcionales y evolutivas entre los sistemas de apareamiento de camarones carideos, y características específicas tales como biología/ecología general, sistemas sexuales, conducta y morfología. Basados en reportes bibliográficos se describió cuatro sistemas de apareamiento, y un quinto fue reconocido pero la información disponible fue insuficiente para describirlo en detalle. 'Monogamia' ocurre en muchas especies que habitan en refugios monopolizables o huéspedes, especialmente cuando las condiciones ambientales restringen la probabilidad de encuentros entre conespecíficos. En contraste, las especies de vida libre experimentan encuentros más frecuentes y los machos pueden dominar o buscar: En el sistema de apareamiento 'dominancia vecinal' los machos más grandes rinden mayor éxito reproductivo porque son los que tienen el mejor desempeño en la competencia agresiva por las hembras receptivas. En el sistema 'pura búsqueda' son los machos pequeños los que lo hacen mejor porque su agilidad les permite buscar pareja eficazmente entre la población. El cuarto sistema de apareamiento es ‘búsqueda \& compañía' que ocurre en simbiontes solitarios que experimentan condiciones demográficas y ecológicas variables: dependiendo de las condiciones ambientales y del estado ontogenético, puede ser conveniente para los machos buscar o permanecer en huéspedes con hembras sexualmente atractivas. Los sistemas sexuales de los carideos se caracterizan por su diversidad y plasticidad intraespecífica, habiendo especies gonocóricas, otras con diferentes formas de hermafroditismo protándrico e incluso hermafroditas simultáneas. Los sistemas de apareamiento identificados parcialmente explican esta diversidad: en especies monogamas las bajas tasas de encuentro y la falta de dimorfismo sexual, favorecen el hermafroditismo simultáneo pero la gonocoría normalmente domina posiblemente porque las 
parejas no son estrictamente fieles. Especies con dominancia vecinal son gonocóricas porque ambos sexos se benefician con ser grandes. Las especies con pura búsqueda tienen una amplia oportunidad para la evolución de protandría ya que los más beneficiados son los machos pequeños y las hembras grandes. En especies con búsqueda \& compañía la situación es variable, solo algunos machos se benefician al ser suficientemente grandes, mientras que otros lo hacen mejor buscando o cambiando de sexo. En comparación con otros crustáceos, los camarones de vida libre se caracterizan por la ausencia de custodia precopulatoria e infrecuentes conductas agresivas. La eficiente y característica conducta de escape de los camarones usando su abdomen contractil podría ser un importante impedimento para la evolución de tales conductas. Nuestra revisión provee buenos indicios de que los sistemas de apareamiento de camarones carideos dependen tanto de características ambientales como biológicas propias de este taxón.

Palabras clave: Caridea, conducta de apareamiento, sistema de apareamiento, dimorfismo sexual, sistema sexual.

\section{INTRODUCTION}

The mating behavior of crustacean decapods has received considerable attention during the last few decades (Knowlton 1980, Nakashima 1987, Bauer 1996, Jivoff \& Hines 1998, Bauer \& Abdalla 2001). Most recent contributions deal with mechanisms of sexual selection influenced by both male and female behavior during courtship (e.g., Ra'anan \& Sagi 1985, Christy 1987, Jivoff 1997, Rondeau \& SainteMarie 2001). In addition to the most apparent mechanisms of sexual selection such as male fighting (e.g., Correa et al. 2003) less evident interactions such as sperm competition are receiving increasing attention, yet their evolutionary consequences remain in debate (Diesel 1990, Urbani et al. 1998). One important aspect, which may influence the mode in which sexual selection operates over a variety of life history traits is the way in which males and females coincide in space and time preceding mating (Christy 1987). This view focuses mainly on behavioral, social and ecological circumstances prior to mating, which may constrain or affect the interaction between potential mates.

Caridean shrimp are a particularly suitable taxon among decapod crustaceans to study how ecology, reproductive behavior, mating behavior, and sexual selection are related to each other: Species are common in a wide variety of aquatic environments facing different ecological conditions. As an ancestral trait of the Decapoda, most carideans have external fertilization (Bauer 1986a) and their mating behavior is quite variable (Bauer 1976, Ra' anan \& Sagi 1985, Knowlton 1980). Furthermore, while most other decapods have separate sexes during their lifetime, carideans comprise many species that change sex (in diverse patterns) or even present simultaneous hermaphroditism (see Bauer 2000 for an excellent discussion on protandric simultaneous hermaphroditism in caridean shrimp). However, despite the suitability of these crustaceans for the study of evolutionary ecology no attempts have been made - to our knowledge - to synthesize information about mating systems in carideans and place it in a proper theoretical framework.
Even though mating systems in the animal kingdom have long been studied, there is little agreement on a classificatory scheme or even on the main discriminating criteria (Andersson 1994). Herein, we studied the mating systems of caridean shrimp focusing on the way males and females converge in space and time for mating. We followed a similar approach as Christy (1987) for brachyuran crabs, which consisted in reviewing all available information and categorizing the mating systems in order to correlate those behaviors with other biological and ecological variables. One important consideration refers to the criteria used to categorize mating systems: Although it is well known that both males and females play an important role in mating behavior and in determining the outcome of sexual selection, here we mainly consider male behavior for classificatory purposes. Among decapods and other taxa, females represent a limiting reproductive resource for males due to their low potential reproductive rate (see Emlen \& Oring 1977, Kvarnemo \& Ahnesjö 1996 for theoretical considerations). Accordingly, males perform various behaviors in order to find and/or access receptive females (e.g., Borowsky 1983, Nakashima 1987, Bauer \& Abdalla 2001) rendering male behavior a useful tool for classificatory purposes (Christy 1987). Moreover, since males usually are the competing sex, their behavior largely determines other sexually selected mechanisms such as female mate choice and sperm competition (Diesel 1990, Andersson 1994).

Christy (1987) distinguished several ways in which brachyuran crabs secure mating partners. For example, in some species males visually attract females to refuges suitable for safe female reproduction. Males of other species simply search for receptive females, which may release water borne pheromones to attract males. Females also may selectively favor certain male qualities. The specific mechanisms in pair formation depend on factors such as ecological environment, resources required for reproduction, spatial distribution of potential mates, physical attributes, and reproductive biology, 
among others (Christy 1987). A comparative analysis of mating systems therefore requires inclusion of different aspects of life history traits in order to identify the key factors responsible for behavioral diversification and its further consequences.

In the following, we first describe general aspects of the reproductive biology of caridean shrimp. Then we propose a classification of the different trends in mating systems, identifying only the key ecological factors involved. Finally, we develop a simple conceptual model, describing potential links between the evolution of each mating system and morphological and reproductive traits.

\section{MATERIAL AND METHODS}

We reviewed studies published during the past two decades that describe the reproductive behavior and general ecology of caridean shrimp. With the information obtained from these studies, we constructed a data matrix with rows for each species and columns for several descriptive characters regarding reproductive biology, behavior, ecology and morphology (see results \& discussion). The data matrix comprises all species for which sufficient information could be obtained to enter at least one of the analyses presented below. The complete data matrix is available upon request.

\section{RESULTS AND DISCUSSION}

We obtained information about the reproductive behavior and/or other related ecological and bio- logical variables for 76 species from nine families (out of 30) of caridean shrimp. Note that each of these species had sufficient information to enter in at least one of the analyses presented below. Although for some species we obtained information for several characters permitting a better understanding of the phenomena we were interested in, for many other species we only obtained specific reports or anecdotal observations of particular aspects. Also for some characters the data matrix contains information for many species while for others information was scarce or absent (Table 1).

\section{Sexual systems}

One important outcome of the analysis of the reproductive biology of caridean shrimp is the high diversity of their sexual systems, i.e. there are several different ways in which individuals even of the same species may develop sexually. For 45 species (from seven families) explicit information -or strong indirect evidence- on their sexual system was available. Of these, 16 species (from five families) are gonochoristic (i.e., all individuals in the population exhibit separate sexes throughout their lifetime), and 29 species (from five families) present one of five types of protandric hermaphroditism (i.e., individuals who pass through a male phase followed by a female or simultaneous hermaphrodite phase). Some sexual systems are complex since some species (populations) have no unique sex determination but a mixture of patterns (Table 2).

Since most other decapods are gonochoristic (see revision of decapod sexual systems in Bauer

TABLE 1

List of the main variables included in the data matrix discussed in this paper and number of species for which any related information was found

Lista de las principales variables incluidas en la matriz de datos que se discute en este articulo, y número de especies para las cuales se encontró cualquier información relacionada

\begin{tabular}{lclclc}
\hline $\begin{array}{l}\text { Ecology, demography } \\
\text { and morphology }\end{array}$ & Number & $\begin{array}{l}\text { Reproductive biology } \\
\text { and reproductive behavior }\end{array}$ & Number & $\begin{array}{l}\text { Social behaviors and } \\
\text { mating systems }\end{array}$ & Number \\
\hline Families & 9 & Sexual system & 45 & Communication signals & 15 \\
Species & 76 & Reproductive seasonality & 35 & Social behavior & 20 \\
Geographic distribution & 67 & Molting synchrony & 8 & Any competition? & 16 \\
Habitat & 55 & Duration of female reproductve cycle & 15 & Mating system (this study) & 30 \\
Population density & 28 & Sexual receptivity & 19 & & \\
Spatial distribution pattern & 17 & Mate guarding & 18 & & \\
Population structure & 35 & Duration of mating & 12 & Total number of references \\
Operational sex ratio & 4 & Sperm storage & 15 & included in the data matrix & $>40$ \\
Sexual dimorphisms & 38 & Developmental mode & 29 & &
\end{tabular}


2000), researchers in the past may have omitted to identify or report explicitly the sexual system of their focus species. At present it appears premature to speculate on the frequency of occurrence of one or the other sexual system among caridean shrimp. However, given the high diversity of sexual systems among the Caridea, it becomes evident that it is important to identify and explicitly report this information in future studies on species from this taxon.

Species from many families, such as Pandalidae, present various forms of hermaphroditism, while in other families all species appear to be gonochoristic (Table 2). For example, there are no reports of any kind of hermaphroditism for Palaemonidae despite the fact that many species present sexual dimorphism with smaller males (Berglund 1981, Omori et al. 1994, Bauer \& Abdalla 2001). This is a characteristic of protandric species [see the size advantage model by Ghiselin (1969) in Warner (1975); e.g., Boddeke et al. 1991, Bauer \& VanHoy 1996]. The fact that particular sexual systems predominate within some families suggests that one source of variation on sexual systems are phylogenetic constraints. This is a major concern for the study of the evolutionary

\section{TABLE 2}

Sexual systems present in Caridea. The list includes 42 species with explicit reports or strong indirect evidence of their sexual systems. Three species with unspecified forms of protandric hermaphroditism are not listed herein

Sistemas sexuales presentes en Caridea. La lista de especies incluye a 42 que presentaron información explícita acerca de sus sistemas sexuales, o evidencia indirecta sustancial. Tres especies con un tipo no especificado de hermafroditismo protándrico no fueron listadas aquí

Sexual system: definition

Family: species

Gonochorism: all adult individuals reproduce as males or females throughout their life-time

Alpheidae: Alpheus angulatus (1); A. armatus? (2), A. inca? (3), Alpheopsis chilensis? (3)

Hippolytidae: Thor dobkini (4), T. floridanus (4), Heptacarpus pictus (5)

Palaemonidae: Macrobrachium rosenbergii $(6,7)$, Palaemontes pugio $(8)$

Pandalidae: Heterocarpus ensifer (9), H. gibbosus (9), H. laevigatus (9), H. sibogae (9), Pandalus propinquus (10), Plesionka longirostris (9)

Rhynchocinetidae: Rhynchocinetes typus (11)

Protandrous hermaphroditism: all adult individuals reproduce first as males and then as females

Crangonidae: Notocrangon antarcticus (12)

Hippolytidae: Chorismus antarcticus (13)

Pandalidae: Pandalopsis dispar (14), Pandalus eous (15), P. goniurus (16), P. latirostris (15), P. platyceros (14)

Partial protandric hermaphroditism: only a portion of adult population changes sex (sexchangers)

Partial protandric hermaphroditism with primary males: there are sex changers and permanent males

Alpheidae: Athanas indicus? (17), A. kominatoensis (18)

Pandalidae: Pandalus hipsinotus (19)

Partial protandric hermaphroditism with primary females: there are sex changers and permanent females

Crangonidae: Argis dentata (20), Crangon crangon (21)

Pandalidae: Pandalus borealis (22), P. danae (23), P. montagui (24), P. jordani (25)

Processidae: Processa edulis (26)

Partial protandric hermaphroditism with primary males and females: there are sex changers and permanent males and females Hippolytidae: Thor manningi (4)

Protandric simultaneous hermaphroditism: adults first reproduce as males and then as simultaneous hermaphrodites with outcrossing Hippolytidae: Exhippolysmata ensirostris (27), Lysmata amboinensis (28), L. californica (29), L. debelius (28), L. grabhami (30), L. nilita (31), L. seticaudata? (32), L. wurdemanni (33)

References: (1) Personal observation LM Mathews, (2) Knowlton 1980, (3) Personal observation M Thiel, (4) Bauer \& VanHoy 1996, (5) Bauer 1976, (6) Ra'anan \& Sagi 1985, (7) Kuris et al. 1987, (8) Bauer \& Abdalla 2001, (9) King y Moffitt 1984, (10) Squires 1965 in Bergström 2000, (11) Personal observation C Correa, (12) Retamal 2000, (13) Clarke 1985, (14) Butler 1964, 1980 in Bauer \& Holt 1998, (15) Kurata 1981 in Bergström 2000, (16) Butler 1964, 1980 in Bauer 2000, (17) Gherardi \& Calloni 1993, (18) Nakashima 1987, (19) Butler \& Kurata 1981 in Bergström 2000, (20) Fréchette et al. 1970 in Bauer \& VanHoy 1996, (21) Bodekke et al. 1991, (22) Bergström 1997, (23) Marliave 1997 \& Butler 1980 in Bergström 2000, (24) Mistakidis 19576 Simpson et al. 1970 in Bergström 2000, (25) Dahlstrom 1970 \& Butler 1980 in Bergström 2000, (26) Noël 1976, in Bauer 2000, (27) Kagwade 1982 in Bauer \& Holt 1998, (28) Fiedler 1998, (29) Bauer 2000, (30) Wirtz 1997 in Bauer \& Holt 1998, (31) Dohrn \& Holthuis 1950 in Bauer 2000 (32) Berreur-Bonnefant \& Charniaux-Cotton 1965 in Bauer \& Holt 1998, (33) Bauer \& Holt 1998 
consequences of mating systems. Nevertheless, families such as Hippolytidae present variable sexual systems even between congener species that are ecologically related (Bauer \& VanHoy 1996). This is good evidence that there are rather plastic mechanisms determining the sex of individuals. Evolutionary ecologists have been discussing that sex change could be mediated through social interactions in some species (Nakashima 1987, Gherardi \& Calloni 1993). This would mean that the mechanisms may be plastic on ecological time scales offering the possibility to explore experimentally the proximate causes leading to sex change. For example all individuals of Athanas kominatoensis (Alpheidae) achieve sexual maturity with a male gonad but at some point many individuals start developing a female portion of the gonad accompanied by a degeneration of the initial male character. Only the largest males at the beginning of the reproductive season do not change their sex and continue to grow as functional males. This phenomenon is believed to be mediated by social interactions (Nakashima 1987, see further discussion in Charnov et al. 1978, Charnov 1979, Charnov \& Anderson 1989, Gherardi \& Calloni 1993). With respect to this question, Bergström (1997) examined whether the observed variations in age/size of sex change of the pandalid shrimp Pandalus borealis are responses to fluctuations of the population's demography. The yearly variations in age/size/sex structure did not significantly affect the timing of sex change in the four demes studied, thus not supporting the notion of environmental sex determination through social interactions. Alternative explanations based on genetic polymorphism were suggested, but the author also emphasizes (as do most other authors) that future studies are required (Bergström 1997, 2000).

\section{When are females and males willing to mate?}

For 19 species from seven families information was available about the timing of female sexual receptivity. Invariably female receptivity is linked to the reproductive molt. In all species, females are receptive only for short time periods (from few min to $<3$ d) relative to the length of the reproductive cycle (weeks to months). Female receptivity associated to molting is also the most common (but not unique) pattern among other crustaceans (amphipods - e.g., Borowsky 1983, isopods - e.g., Shuster 1989, some penaeid shrimp - e.g., Bauer 1996, stenopodid shrimp - e.g., Zhang et al. 1998, brachyuran crabs - e.g., Rondeau \& Sainte-Marie 2001, anomuran crabs e.g., Wada et al. 1997). At the population level, females of many caridean species appear to acquire their receptivity asynchronously, i.e., there are always only few females receptive within the population (Mathews 2002a, also deducible from Nakashima 1987 and Bauer 1989). Male receptivity, in contrast, has received comparatively little attention since it is generally assumed that adult males are sexually active during the entire intermolt hard-shelled phase (i.e., most of the time). Mating experiments conducted with other objectives indirectly support this assumption (e.g., Bauer 1976, 1996, Ra' anan \& Sagi 1985, Boddeke et al. 1991, Bauer \& Holt 1998, Correa et al. 2000), but at present there exists little information about potential reproductive rates of males. In male rock shrimp Rhynchocinetes typus, ontogenetic male stages differ in their sperm allocation strategies. Small males invest more of their sperm products in their first mating, while large males spend less on each female but do better in consecutive matings (Hinojosa \& Thiel in press). Thus, it is possible that males experience sperm limitations, but their potential reproductive rates may still be substantially higher than those of females (for general discussion see also Kvarnemo \& Ahnesjö 1996). Male reproductive potential has been better studied in brachyuran crabs. Following two copulations, male blue crabs Callinectes sapidus require approximately nine days to recover a vas deferens weight similar to males deprived from females (Kendall \& Wolcott 1999). Similarly, Jivoff (1997) demonstrated that male blue crabs require approximately $15 \mathrm{~d}$ after a first copulation to achieve similar-sized ejaculates in a second copulation. Female snow crabs Chionoecetes opilio that mated with "mating-exhausted' males produced clutches with few or no fertilized eggs, indicating effective sperm limitation in males (Rondeau \& Sainte-Marie 2001). Thus, there exists ample evidence suggesting that reproductive rates of male crustaceans (shrimp) are also limited by production of gametes, albeit not to the same extent as those of females.

Mating activity also depends on season: some species reproduce year-round while others feature different degrees of seasonality. Information on seasonality versus geographic distribution is available for 28 species from nine families. Not surprisingly, highly seasonal species (> $75 \%$ of potentially reproductive females do not reproduce during some months) are more frequent in temperate than in tropical regions. However, there is also one highly seasonal tropical species (out of 14 tropical species). In general, though, the frequency of highly seasonal species is significantly higher for temperate species (nine out of 14 species) ( $2 \times 2$ contingency table, Yates cor- 
rected Chi-square $=7.62, \mathrm{P}=0.0058)$. This pattern agrees with Bauer's (1989) empirical demonstration of increasing seasonality in carideans at higher latitudes. During the main breeding season, most females reproduce continuously such that they experience simultaneous development of incubated embryos and new gametes (Bauer 1976, 1986b, 1989, Nakashima 1981, Damrongphol et al. 1991, Bauer \& Abdalla 2000). Temporal reproductive latency has been reported only for females of the palaemonid shrimp Macrobrachium rosenbergii (Damrongphol et al. 1991). For males, there exists very little information about reproductive seasonality but at least Bauer (1976) observed in Heptacarpus pictus that sperm production ceases outside the reproductive season.

\section{Operational sex ratio and adult sex ratio}

The proportion of receptive females to sexually active males, namely 'operational sex ratio', is the most important parameter determining the intensity and direction of competition for mates (Emlen \& Oring 1977). Although there are no empirical estimations of this parameter, various authors agree that the operational sex ratio in most caridean shrimp (as in other crustaceans) should be strongly biased towards males (Knowlton 1980, Nakashima 1987, Bauer \& Abdalla 2001, Correa et al. 2003). This conclusion is based on the assumption that males are almost always prepared to mate in contrast to females that have more limited reproductive rates and become receptive asynchronously (see previous section). The consequence should be strong intrasexual competition among males to fertilize the relatively scarce receptive females that are available at any given time (Emlen \& Oring 1977).

The adult sex ratio is the component of the operational sex ratio that is easiest to obtain. Consequently, explicit information (or estimates deducible from population structure) of this parameter are available for a comparatively large number (29) of species. For 17 of these species, we found that the proportion of adult males and females usually was nearly even. The remaining species showed rather pronounced biases of the adult sex ratio: most (eight) of these latter species had a preponderance of males while in two species females where more abundant. The remaining two species showed temporal or spatial variation with either males or females predominating at different times.

For 19 species, both the sexual system and the adult sex ratio are known. Twelve out of thirteen gonochoristic species feature an even adult sex ratio. In contrast, this was found in only one out of six species with any degree of hermaphroditism rendering a significant relation between the sexual system and the adult sex ratio $(2 \times 2$ contingency table, Yates corrected Chi-square $=$ $7.65, \mathrm{P}=0.0057)$.

\section{Signaling}

Social interactions among shrimp might be mediated by combinations of several rather than single signals (Hughes 1996). Visual signals are apparent in agonistic displays of many species and may serve for mutual assessment of the fighting potential of opponents (Nakashima 1987, Gherardi \& Calloni 1993, Hughes 1996, Barki et al. 1997, Correa et al. 2003). Sexual recognition may be visual, especially in species with sexual dimorphism, but at present too little is known about this topic in caridean shrimp (but see Knowlton 1980). Instead many observations suggest that, at least during courtship, males usually recognize a receptive female upon contact implicating chemo-tactile signals (Bauer 1976, Ra'anan \& Sagi 1985, Correa et al. 2000). Similar mechanisms have been observed in other small crustaceans (e.g., Peracarida, Jormalainen 1998). Distance pheromones used as sex attractants are uncommon among carideans (a probable exception is Crangon crangon, Boddeke et al. 1991). However, their use in individual recognition and pair formation of monogamous species has been suggested (Seibt 1973 in Bauer 1976, Hughes 1996). The limited use of attractive water-borne pheromones by caridean females contrasts to brachyuran crabs where females commonly use them (Bouchard et al. 1996 and papers cited therein). Several intertidal or semi-terrestrial male crabs also use visual signals to attract females (e.g., Christy et al. 2001) a behavior, which has not been reported for Caridea. These are important differences since these signaling mechanisms represent an essential component of the mating system (Christy 1987).

Sperm transfer, spawning, fertilization, and brooding

In general, female carideans have no sperm storage structures: 10 out of 15 species for which explicit information is available lack such structures and based on all available evidence it appears safe to assume that they are absent in most carideans. Therefore, females need to copulate during each reproductive cycle - otherwise they 
spawn and lose unfertilized eggs (Bauer 1976, 1989, Damrongphol et al. 1991, Correa et al. 2000, Bauer \& Abdalla 2001) [Athanas nitescens (Alpheidae) is the only reported species where spawning is suppressed in absence of males (Nouvel \& Nouvel 1937 in Bauer 1976)]. The only species for which sperm storage structures have been suggested are three species from the family Processidae, which have a closed thelycum (a ventral pouch that may serve to store sperm, albeit only within one reproductive cycle; Bauer 1986a). The species Atyaephyra desmaresti (Atyidae) possesses an open thelycum, which probably is a less efficient structure than the closed thelycum to store sperm (Descouturelle 1971 in Bauer 1986a). The sand shrimp Crangon crangon (Crangonidae) represents another special case in that the male deposits sperm into the female's oviducts, which may also serve as a sperm reservoir (Boddeke et al. 1991).

Detailed descriptions or anecdotal observations of the copulatory behavior have been reported for only eight species from five families. Sperm transfer consists in brief but usually repeated movements of the male's thorax-abdomen junction towards the ventral side of the female. These movements are very fast, which makes it difficult to observe the exact mechanism of sperm transfer (see Bauer 1976, Boddeke et al. 1991, Correa et al. 2000). However, morphological analysis and amputation experiments have shown that the modified male pleopods 1 and 2 mediate transfer of spermatophores to the ventral side of females (see Bauer 1976): when males are ready, they adopt the proper position relative to the female and eject at least part of the vas deferens contents (spermatophores), which briefly remain close to their gonopores on the coxae of the 5 th pereopods. Spermatophores (a sticky and dense bandshaped mass containing immobile sperm) apparently are immediately pushed by the modified male pleopods onto the ventral region of the female abdomen or posterior thoracic sternites (i.e., to the region of the female body where eggs pass during transport to the abdomen; Bauer 1976). A substantially different sperm-transfer mechanism was suggested only for Crangon crangon (Boddeke et al. 1991). Males of this species apparently transfer their sexual products directly from their gonopores into the females' oviducts effectively resulting in internal fertilization of the eggs. Sperm transfer may also deviate from the general trend in species of the Processidae, in which females possess a closed thelycum, and of the Hippolytidae in which simultaneous hermaphrodites can mate as males despite having embryos attached to their pleopods (Bauer \& Holt 1998, Fiedler 1998).

Females always spawn soon after copulation (or during mating), and furthermore it has been suggested for some species that mating stimulates female spawning (Damrongphol et al. 1991, Correa et al. 2000, Bauer \& Abdalla 2001). During the spawning process, females extrude and move batches of eggs from the gonopores (in the coxae of the $3^{\text {rd }}$ pereopods) towards the ventral part of their abdomen. Each egg batch is extruded when the female arches its body and the pleopods are directed forward, suggesting that pleopods facilitate the passage of eggs from the gonopores to the abdomen (Bauer 1976, Correa et al. 2000). Previously transferred sperm is located on the posterior thoracic sternites or between the pleopods allowing external fertilization of the extruded eggs. The eggs or zygotes soon thereafter become attached to the pleopods where they remain during embryonic development. The spawning process may last from approximately 20 to $>120$ min (Bauer 1976, Correa et al. 2000), and proper attachment of the fertilized eggs to the pleopods probably requires some more time. This renders the female particularly susceptible to loss of eggs during this time period (personal observation). All carideans show some degree of parental care, but following incubation of developing embryos most species release planktonic larvae (26 out of 29 species from nine families), with the exception of some Alpheidae, which care for offspring until juveniles stages (Duffy 1996a, 1998, Duffy \& Macdonald 1999).

\section{Mating systems}

For 30 species from seven families we found sufficient information to allow us to infer about the way in which mates meet to proceed to the pseudo-copulation. We distinguished four general categories, based mainly on the behaviors that males adopt to obtain matings. A fifth category (queen-centered mating, i.e., eusociality sensu Duffy 1996a) was introduced for some alpheid species with a particular social organization, which affects their population structure, life history and most likely their mating system (see Duffy \& Macdonald 1999, Duffy et al. 2002). However, at present no information is available on the mating behavior of these synalpheid shrimp preventing further analysis of their mating system. The remaining four mating systems are described below (see summary of mating systems in Table 3 and categorized species in Appendix 1). 


\section{TABLE 3}

Summary and main characteristics of mating systems identified in Caridea. The category 'eusociality' is not included in this table since at present there is insufficient information about this mating system (see text)

Resumen y principales características de los sistemas de apareamiento identificados en Caridea. La categoría 'eusocialidad' no se incluyó en esta tabla debido a la falta de información respecto de este sistema de apareamiento (ver texto)

Monogamy. Adult individuals associate with a member of the opposite sex to reproduce and share one microhabitat (a refuge or host) for a long time period exceeding one reproductive cycle. Mates behave territorially towards conspecific intruders. There is usually no extra-pair mating.

Neighborhoods of dominance. Male mating success depends largely on their ability to win aggressive encounters to overtake and defend receptive females. Pair formation is restricted to a short period (few hours) of female receptivity. During this time dominant males attend, fertilize and guard females (i.e., throughout the spawning process) after which mates separate.

Pure search. Male mating success depends primarily on their ability to find (and mate with) as many receptive females as possible. To search efficiently, these males roam through the population and continually contact conspecifics until they find a receptive female. Upon locating such a female, males transfer sperm in brief and simple acts after which the pair immediately separates. There are no complex behaviors such as courtship of receptive females, nor aggressive encounters between males.

Search and attend. Adults live solitarily on hosts (or in other refuges), but males change hosts frequently in search of females close to reproductive receptivity. Upon finding such a female, males stay on the hosts and prevent takeovers by fighting. Following mating, each mate returns to a solitary life-style.

\section{Mating system: monogamy}

Many authors use monogamy to refer to longlasting pair formation, but usually the exact degree of mate fidelity is unknown. Monogamy is the most common mating system among Alpheidae (eight species) but it also occurs in Gnathophyllidae (one), Hippolytidae (two) and Palaemonidae (one). Monogamy is a particular tactic of ensuring a mate among crustaceans, and it commonly is based on the fidelity of individuals from both sexes to stay, defend and share a specific microhabitat or refuge. Refuges are discrete and monopolizable by a heterosexual pair or simultaneous hermaphrodites - and are essential for shrimp survival (see Thiel \& Baeza 2001). The refuge may be an invertebrate host in the case of symbionts (e.g., sea anemones for Alpheus armatus, Knowlton 1980), a cavity in corals (e.g., Alpheus idiocheles, Kropp 1987) or burrows in gravel substrata (e.g., Alpheopsis chilensis, Boltaña \& Thiel 2001). The limited probabilities of males to find additional mating partners is thought to be one of the main causes for the evolution of long-lasting pair formation in crustaceans and other taxa (Jormalainen 1998). Continuous fidelity towards mates (i.e., monogamy) is the extreme expression of this trend. Among the carideans, low population densities, dispersed distribution of refuges and high predation pressure (outside the refuges) are probably key fac- tors limiting encounter probabilities between males and extra-pair females (see Knowlton 1980, Bauer 2000, Thiel \& Baeza 2001). Indeed, laboratory experiments and field observations on monogamy-based mating systems demonstrate that favorable environmental conditions (i.e., an excess of females or low predation pressure) positively affect the propensity of males to search for additional females (Knowlton 1980, Mathews 2002a). An additional element contributing to the monogamous life-style is that both males and females are likely to benefit by dividing the labor of refuge defense, maintenance and food acquisition as was partially demonstrated for Alpheus angulatus (Mathews 2002b).

Since fecundity in females of all caridean species (and crustacean females in general) is positively correlated with female body size (e.g., Knowlton 1980, Bauer 1986b, Nakashima 1987, Duffy \& Macdonald 1999, Oh \& Hartnoll 1999), males that reproduce faithfully with a single female during their lifetime should show a similar lifetime reproductive output as their female partners (Fig. 1A). Sexual selection in this scenario should be weak particularly if the adult sex ratio is balanced (Andersson 1994). For none of the 12 species with monogamy a biased sex ratio has been reported. Accordingly, if sexual selection is weak, disproportionate sexual dimorphism of secondary sexual characters is not expected (Andersson 1994). For only three from these 12 


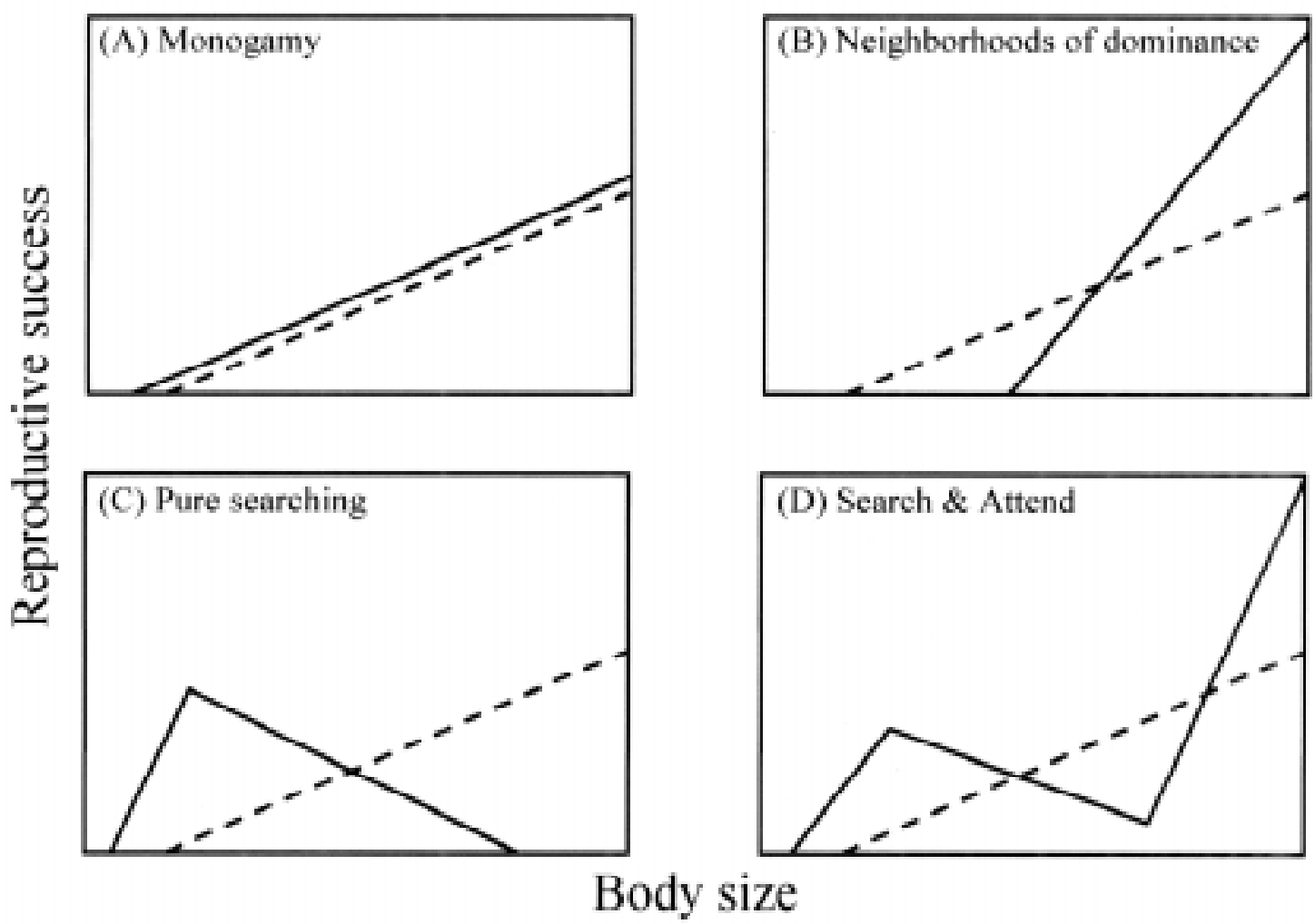

Fig. 1: Reproductive success of males and females relative to their body size in different mating systems. Solid lines $=$ male functions, dashed lines $=$ female functions. Females reproductive success always increase with size because the larger the female the more eggs she can produce and brood. (A) In the mating system with 'monogamy' males increase their reproductive success in the same way as their mates because they have no extra-pair copulations; (B) when the primary male reproductive strategy is 'neighborhoods of dominance' their reproductive success increases sharply with the size (and weaponry) because when males outgrow their competitors they may obtain consecutive copulations; (C) in males that engage in 'pure searching', small size is advantageous because of the higher agility, lower energetic costs, and low conspicuousness to predators; (D) 'search and attend' mating systems are characterized by a mixture of pure searching and dominance components (see text) [conceptual model D re-drawn after Nakashima (1987) and Gherardi \& Calloni (1993)].

Éxito reproductivo de machos y hembras en relación al tamaño corporal en distintos sistemas de apareamiento. Líneas continuas $=$ funciones de machos, líneas entrecortadas $=$ funciones de hembras. El éxito reproductivo de las hembras siempre incrementa con el tamaño porque entre mayor éste es, más huevos puede producir y criar. (A) En el sistema de apareamiento 'monogamia', los machos incrementan su éxito reproductivo de la misma manera que sus parejas porque no copulan con hembras adicionales; (B) cuando el sistema de apareamiento preferido para los machos es 'dominancia vecinal', su éxito reproductivo aumenta agudamente con el tamaño (y armamento) porque los machos relativamente grandes pueden obtener cópulas sucesivas; (C) en los machos que incurren en 'pura búsqueda', un tamaño pequeño es ventajoso por su mayor agilidad, bajos costos y baja notoriedad ante predadores; (D) el sistema de apareamiento 'búsqueda \& compañía' se caracteriza por una mezcla de componentes de dominancia y búsqueda (ver texto) [el modelo conceptual D fue redibujado a partir de Nakashima (1987) y Gherardi \& Calloni (1993)].

species some sexual dimorphism in body and/or chelae size has been reported (Appendix 1): in Alpheus armatus and Alpheus angulatus males have a slightly (A. armatus) or substantially larger (A. angulatus) snapping chelae than their mates, and male Periclimenes ornatus have smaller body but larger chelae size than their female partners (Knowlton 1980, L. Mathews personal communication, Omori et al. 1994, respectively). At least for the two former species it is known that mate fidelity is not strict (Knowlton 1980, Mathews 2002a), which allows a certain degree of sexual selection favoring larger chela for male-male competition (Andersson 1994). The remaining species apparently lack pronounced dimorphisms of secondary sexual characters. Typically pairs are found assorted by size, and mates usually are size-matched (Knowlton 1980, Boltaña \& Thiel 
2001). Amphipods with precopulatory mate guarding also show size-assortative mating but males usually are larger than females since pair formation is mostly driven by male-male competition (Iribarne et al. 1996, Jormalainen 1998). If mates in pairs would be strictly faithful, one could assume that males could be smaller than females since small males would still be capable to fertilize a clutch of eggs from a large female. Sizematched assortment where both mates have similar sizes may be consequence of a certain need to control the mate and defend it against extra-pair matings. Whether size-assortative associations in heterosexual pairs and the common lack of sexual dimorphism with smaller males in monogamous caridean shrimp is consequence of a certain level of intrasexual interactions with extra-pair conspecifics, requires further research.

Since there is no sexual dimorphism in body size (most common in monogamous species) protandric hermaphroditism is unlikely to evolve (Ghiselin 1969 in Warner 1975). Nevertheless, there exists a 'window' for the evolution of simultaneous hermaphroditism, particularly at low population densities when the encounter probabilities between the sexes are low (Ghiselin 1969 in Warner 1975). Gonochorism is also likely to occur when mates show some degree of infidelity - males may gain by mating with neighboring females. Despite the limited information available, our review partially supports these predictions. There are no reported cases of pure protandric hermaphrodites but two cases of protandric simultaneous hermaphrodites, which are symbionts of sea anemones and occur at low densities (see 'sexual systems' chapter for definitions) (see Bauer 2000, 2001). The two species for which some degree of opportunistic infidelity has been mentioned above are gonochoristic (Knowlton 1980, L. Mathews personal communication). The eight remaining species also are gonochoristic or have unknown sexual systems (Appendix 1) (see also above: sexual systems).

\section{Mating system: neighborhoods of dominance}

The mating system reported for two free-living species, one from the Palaemonidae and one from the Rhynchocinetidae, is characterized by males that establish dominance hierarchies among their neighbors. Aggressive displays are common between males and may be used in conflicts about space, food acquisition and more importantly access and defense of receptive females (Ra' anan \& Sagi 1985, Karplus \& Harpaz 1990, Correa et al. 2003). Males of both species have evolved com- plex and stereotyped (or ritualized) agonistic behaviors accompanied by morphological adaptations for fighting (Karplus \& Harpaz 1990, Correa et al. 2003). If males are dominants among neighbors they can overtake and defend receptive females performing a series of behavioral events beyond transferring spermatophores (Ra' anan \& Sagi 1985, Correa et at. 2000, 2003). Male defense of the female may last a few hours until females have almost completed the spawning process thereby ensuring paternity for most of the clutch (see Correa et al. 2000). Thus, male size and weaponry (by affecting their defense potential) is positively correlated with their mating success as reported for many other crustaceans (amphipods - e.g., Borowsky 1985, Conlan 1989, Clark 1997; brachyuran crabs - e.g., Jivoff \& Hines 1998, Rondeau \& Sainte-Marie 2001; anomuran crabs - e.g., Wada et al. 1997). Although it is expected that females favor dominant males under these circumstances (e.g., because of genetic advantages or for female protection during spawning) female preference for certain males has not yet been clearly demonstrated (but see Hinojosa 2001). Smaller males, unable to succeed in direct competition with dominants, have shown a high degree of behavioral plasticity. Making the best of a bad situation they are able to shift their mating behavior towards a simplified mating tactic (similar to 'pure searching' see below) when exposed to a limiting social environment (Ra'anan \& Sagi 1985, Correa et al. 2003). Apparently, in these caridean shrimp there is no male precopulatory mate guarding with body contact, which is in contrast to crabs with similar male defense behavior (Jivoff \& Hines 1998, Rondeau \& Saint-Marie 2001). However, other less obvious forms of precopulatory mate guarding such as spatial association cannot be discarded at present (Borowsky 1983, Ridley 1983 in Bauer \& Abdalla 2001, Jormalainen 1998).

In these species with neighborhoods of dominance, the reproductive success function of males based on their body size has a higher elevation than that of females (Fig. 1B). This occurs because when outgrowing their competitors the resource holding potential of males increases such that they have good possibilities to monopolize several (subsequent) matings. While males can thus fertilize several clutches in a relatively short time period, females can only complete one reproductive cycle during the same time period, yielding a lower reproductive success per unit of time.

Based on the above it can be hypothesized that sexual selection should be intense among males of these species, favoring sexual dimorphism with males larger in body size and weaponry 
(Andersson 1994). Indeed, both species with a dominance-based mating system feature extreme sexual dimorphism (Appendix 1). Males grow to larger sizes than females and develop disproportionately large fighting structures (Kuris et al. 1987, Correa et al. 2000).

Protandric hermaphroditism is unlikely in these species since growing males expect greatest reproductive success if they maintain their sex. Possibly protogynic hermaphroditism (i.e., female phase followed by male phase) could be conceivable (e.g., fish - Warner 2001), but reproducing first as a female would mean losing the opportunity to mature first as a male and possibly succeed in fertilizing a clutch (cost). Furthermore, protogyny would yield a low return due to limited reproductive success of small females (low fecundity). Thus, gonochory should prevail among species in which the mating system is based on dominance, as is the case for both species in this category (Appendix 1).

\section{Mating system: pure searching}

Probably 'pure searching' is the most common mating systems among free-living carideans. It has been suggested for 11 species from four families: Crangonidae (one species), Hippolytidae (four), Palaemonidae (two), Pandalidae (four). It has been hypothesized that the reproductive success of searching males depends on their ability to find and fertilize as many receptive females as possible rather than on their physical defense power (see Bauer \& Abdalla 2001 and papers cited therein). Once a searching male identifies a receptive female it transfers spermatophores in brief interactions after which mating partners separate again (Bauer 1976, 1979 in Bauer 1986b, Boddeke et al. 1991, Bauer \& Holt 1998, Bauer \& Abdalla 2001). Females may avoid male harassment by fleeing (Bergström 2000) or by burrowing in the sediment as in the case of Crangon crangon (Boddeke et al. 1991). Usually, there are no aggressive interactions between males even in the presence of receptive females (Bauer 1976, 1979 in Bauer 1986b, Boddeke et al. 1991, Bauer \& Abdalla 2001), but some brief competitive interactions among males have been reported (Carlisle 1959 in Bergström 2000).

It has been suggested that small cryptic and agile males would do better in searching than bigger ones (see Andersson 1994, p. 254). For males of some caridean species, an efficient search behavior rather than a strong defense performance could be the preferred tactic for obtaining consecutive mates (see Berglund 1981, Bauer \&
Abdalla 2001). A strong fighting power in malemale contests requires relatively large body and weapon size, characteristics that in addition to their energetic costs may increase conspicuousness to predators and diminish male search performance. Therefore the reproductive success function for searching males should have a peak at a smaller body size than the continuously increasing female function (Fig. 1C).

Even though low population densities are intuitively expected to favor searching there are several species with searching males that live at very high densities (Bauer 1986b, Bauer R \& J Abdalla personal observations). A number of hypotheses can be formulated in order to explain why searching and not defense can also be advantageous at high population densities. Here we suggest two non-exclusive explanations: (i) extremely high costs for males to defend in the presence of too many competitors, and (ii) copulation is restricted to brief encounters in order to avoid conspicuousness to predators (high costs for males and female).

Under these circumstances sexual selection is expected to be intense leading to sexual dimorphism with smaller males (Andersson 1994). Indeed all 11 species of this mating system are sexually dimorphic with females on average larger than males (in no species have males developed fighting structures) (Appendix 1). The size advantage model by Ghiselin (1969 in Warner 1975) predicts a wide opportunity for the evolution of protandric hermaphroditism when males reproduce more efficiently at small size while the opposite is true for females. In fact seven out of the nine species in this category show some degree of protandric hermaphroditism (most are partially protandric) (Appendix 1). However, there are also two gonochoristic species, Heptacarpus pictus (Hippolytidae) and Palaemontes pugio (Palaemonidae), which is unexpected given their clear sexual dimorphism with males being smaller than females (Bauer 1976, Bauer \& Abdalla 2001) (the other two species have unknown sexual systems). Similar patterns (gonochorism but males < females) have also been reported for some tropical deepwater Pandalidae (King \& Moffitt 1984) - future studies should examine whether in deep waters population densities of these shrimp are low, favoring small males in locating receptive females. At least in the palaemonid species gonochory may be due to phylogenetic constraints (see above: sexual systems), while in $H$. pictus, belonging to the Hippolytidae with highly diverse sexual systems, gonochory most likely is due to other (e.g., ecological) causes. Among the hippolytid shrimp other puzzling cases have been identified, such as for example Lysmata 
wurdemanni, which despite living in crowds has evolved protandric simultaneous hermaphroditism (Bauer \& Holt 1998, but see Bauer 2000).

\section{Mating system: search and attend}

At least two species from the family Alpheidae (Athanas spp. living symbiotically on sea urchins), are characterized by their solitary life style. Only a small proportion of sea urchins is inhabited by more than one shrimp, usually a heterosexual pair (with the female being close to become sexually receptive) or by juveniles (Nakashima 1987). Adult males change their host (or refuge) more frequently than females (Nakashima 1987), a behavior that also was observed in the spider crab Inachus phalangium living on sea anemones (Wirtz \& Diesel 1983) and in the amphipod Ampithoe valida, a tube builder (Borowsky 1983). This male behavior might be a costly maneuver considering the high probability of conflicts with adults of any sex (solitary on sea urchins): adults show territorial behavior and defend their hosts against conspecific interlopers (inferred from strong indirect evidence) and the probability of finding an occupied sea urchin is approximately $65 \%$ for Athanas kominatoensis (Nakashima 1987). An additional cost (mortality) could result from exposure to predation during movements between hosts (Knowlton 1980, Gherardi \& Calloni 1993 for another symbiotic caridean species). However, reproductive females close to sexual receptivity are commonly found in heterosexual pairs (Nakashima 1987). Therefore, high costs experienced by males when changing hosts may be compensated by the benefits of finding a nonterritorial (premolt) female. Frequently, pairs are formed even before the female's reproductive molt (Nakashima 1987), which leads to the conclusion that male precopulatory mate guarding centered around host defense occurs in these species (sensu Jormalainen 1998). Males paired with premolt females may face conflicts with other 'searching' males. Large males have an advantage in preventing takeovers by other males (Nakashima 1987, Gherardi \& Calloni 1993). Agonistic displays among males as seen in neighborhoods of dominance mating-system have also been observed in A. kominatoensis and A. indicus, supporting the conclusion that the defense potential of males affects their mating success (Nakashima 1987, Gherardi \& Calloni 1993). However, Nakashima (1987) observed that the pairing rate of males relative to their size is a ' $\mathrm{J}$ ' shaped function rather than the continuously steep function discussed above for males that establish neighborhoods of dominance: in A. kominatoensis, small adult males have an intermediate pairing rate, mid-sized males are rarely found in pairs, and following this minimum the proportion of paired males increased strongly with male size. The size advantage of large males appears to be reinforced by high population densities (Nakashima 1987). Small male advantage (compared to mid-sized males) is likely to result from efficient search behavior, advantageous when females are scarce and dispersed. Athanas kominatoensis males are known to experience changes in population densities, strong seasonal variability in sex ratios, and different host distribution patters (Nakashima 1987), characteristics that should affect the payoff of each male's reproductive tactic.

The characteristic mid-depression of the reproductive success function of males relative to their body size (Fig. 1D), probably had an important role in the evolution of partial protandric hermaphroditism, the sexual system of both species reported to engage in search $\&$ attend (Appendix 1 ). For both A. kominatoensis and A. indicus it has been suggested that sex change is mediated through social interactions (Nakashima 1987, Gherardi \& Calloni 1993): With approaching reproductive season those males that are mid-sized (with low probabilities to mate successfully as males) do better changing their sex. At this moment only larger males who will benefit from their advantage in direct competition do not change their sex. Small males maturing late in the reproductive season, do well first taking advantage of their efficient search ability, and secondly may survive to the next season (Nakashima 1987).

Here, sexual selection - as in dominance-based mating system - should favor large males with well developed weaponry and aggressive behavior. Although the sexual size dimorphism is not as evident in A. kominatoensis as in other species (searchers or defenders) males who maintain their sex tend to be larger than females. Athanas indicus males in contrast are on average smaller than females but larger males of both species feature powerful chelae, which are used in stereotyped aggressive interactions (Nakashima 1987, Gherardi \& Calloni 1993) (Appendix 1).

\section{CONCLUSIONS}

Caridean shrimp comprise a diverse group of crustacean species in terms of their ecology, reproductive biology, and behavior. In carideans there exist several sexual systems besides 
gonochory, which differs from other decapods in which gonochory is by far the most common system (Bauer 2000). Different patterns of protandry are common among carideans, and sex determination can be plastic either on evolutionary or on ecological time scales (see above: sexual systems). As in many other crustaceans, carideans experience a disparity in the time period that adult males and females devote to sexual activities. This results in males commonly competing with other males to find and mate with scarce receptive females (see above: operational sex ratio \& adult sex ratio). Male-male competition can take different forms depending on the mating system (e.g., Borowsky 1983, Christy 1987, Bauer 1996, Jormalainen 1998). For example males can out-compete rivals either by aggressiveness in which case large size is advantageous (defending either females or refuges with females) or by efficiently searching for receptive females in which case small size would be better. Differences in the reproductive success functions relative to male body size compared to females can represent ultimate causes leading to hermaphroditism (Ghiselin 1969 in Warner 1975). While the reproductive success function of females is always positively correlated with size (the larger the females the larger the clutch size), mating systems may primarily affect the shape of the male function and thus represent an important source of variation leading to the observed diversity in sexual systems of carideans.

One important difference between the mating systems of free-living carideans compared to crabs, for example, is the relatively high prevalence of 'pure searching': Christy (1987) recognized eight mating systems for brachyuran crabs and seven of them involved some sort of male defense behavior through aggressiveness (centered around resources or females themselves). Almost all brachyuran species engage in some sort of precopulatory mate guarding during one or more days. The utilization of aggressive behavior and mate guarding also is common in other crustacean taxa (e.g., Anomura - Wada et al. 1997, for Amphipoda and Isopoda see Jormalainen 1998; some Stomatopoda - Caldwell 1991). In contrast aggressiveness among free-living caridean and penaeid shrimp is uncommon (Bauer 1996, this study). Even though a few caridean species present female-centered aggressive defense (here named 'neighborhoods of dominance'), they have no precopulatory mate guarding since defense is restricted only to the relatively short time period when the female is receptive (but precopulatory advances between sexes might occur, as has been suggested for amphipods, e.g., Borowsky 1983).
Free-living shrimp are usually exposed to predation by fishes (Bauer 1976, Berglund 1981, Ojeda \& Fariña 1996, Caillaux \& Stotz 2003) and the most efficient mechanism to avoid predation is to be alert and quickly flee upon predator approach (Arnott et al. 1998, 1999). Shrimp, contrary to many other crustaceans display an efficient escape mechanism, a rapid back-swim propelled by repeated contractions of the abdomen. Probably this characteristic allowed the colonization of diverse habitats including open surfaces easily accessible to predators. Other crustaceans such as crabs may also colonize these habitats but using alternative strategies, e.g., out-growing predators and developing hard exoskeletons (e.g., Wahle 1992). The characteristic escape response of shrimp might explain at least in part the absence of precopulatory mate guarding and the low frequency of aggressive-defense of females by males: For both sexes to pair up for more time than necessary for efficient transfer of spermatophores might increase the risk of becoming vulnerable to visual predators (fishes) and lowering the efficiency of the escape response. Males may be unwilling to spend more time than absolutely necessary with females, and females may resist male attempts to take them into precopulatory embrace. It is well known that females from species with precopulatory mate guarding resist, to some extent, being guarded (Jormalainen 1998). Female shrimp resistance to male embrace might be more pronounced and efficient in caridean shrimp than in other taxa. Hence, the need of freeliving shrimp (carideans or penaeids) to maintain an efficient escape response and females advantage in inter-sexual conflicts might have an important effect on their mating systems.

Caridean species that live permanently associated to relatively safe microhabitats (refuge or host) may depend to a lesser degree on immediate predator escape and consequently show different degrees of precopulatory guarding and aggressive-defense behaviors. When males have limited chances to obtain extra-pair copulations, e.g., due to low population densities, they attend females for long periods or permanently (monogamy). Otherwise males only attend - and aggressively defend - highly valuable females, i.e. those that soon will become receptive, and after mating they depart to search for new mates (Search and attend). Mating systems of these sedentary species and the degree of mate attendance may depend primarily on variations in encounter probabilities among conspecifics.

In summary, the mating systems and the sexual systems of caridean shrimp depend both on phylogenetic (morphological and physiological), de- 
mographic (population density, distribution pattern) and on environmental (habitat, refuge availability, predation pressure) factors. This review demonstrated that environmental variations might cause variations in the mating and sexual system of caridean shrimp. Future studies should examine experimentally to what degree the plasticity of mating and sexual systems is affected by phylogenetic, demographic and environmental factors.

\section{ACKNOWLEDGEMENTS}

We are grateful to the helpful comments of three anonymous reviewers.

\section{LITERATURE CITED}

ANDERSSON M (1994) Sexual selection. Princeton University Press, Princeton, New Jersey, USA. 599 pp.

ARNOTT SA, DM NEIL \& AD ANSELL (1998) Tail-flip mechanism and size-dependent kinematics of escape swimming in the brown shrimp, Crangon crangon. Journal of Experimental Biology 201: 1771- 1784.

ARNOTT SA, DM NEIL \& AD ANSELL (1999) Escape trajectories of the brown shrimp Crangon crangon, and a theoretical consideration of initial escape angles from predators. Journal of Experimental Biology 202: 193-209.

BARKI A, S HARPAZ \& I KARPLUS (1997) Contradictory asymmetries in body and weapon size, and assessment in fighting male prawns, Macrobrachium rosenbergii. Aggressive Behavior 23: 81-91.

BAUER RT (1976) Mating behavior and spermatophore transfer in the shrimp Heptacarpus pictus (Stimpson) (Decapoda: Caridea: Hippolytidae). Journal of Natural History 10: 415-440.

BAUER RT (1986a) Phylogenetic trends in sperm transfer and storage complexity in decapod crustaceans. Journal of Crustacean Biology 6: 313-325.

BAUER RT (1986b) Sex change and life history pattern in the shrimp Thor manningi (Decapoda: Caridea): a novel case of partial protandric hermaphroditism. Biological Bulletin 170: 11-31.

BAUER RT (1989) Continuous reproduction and episodic recruitment in nine shrimp species inhabiting a tropical sea grass meadow. Journal of Experimental Marine Biology and Ecology 127: 175-187.

BAUER RT (1996) A test of hypotheses on male mating systems and female molting in decapod shrimp, using Sicyonia dorsalis (Decapoda: Penaeoidea). Journal of Crustacean Biology 16: 429-436.

BAUER RT (2000) Simultaneous hermaphroditism in caridean shrimps: a unique and puzzling sexual system in the Decapoda. Journal of Crustacean Biology 20 (special number 2): 116-128.

BAUER RT (2001) Hermafroditismo en camarones: el sistema sexual y su relación con atributos socioecológicos. Interciencia 26: 434-439.
BAUER RT \& R VANHOY (1996) Variation in sexual systems (protandry, gonochorism) and reproductive biology among three species of the shrimp genus Thor (Decapoda: Caridea). Bulletin of Marine Science 59: 53-73.

BAUER RT \& GJ HOLT (1998) Simultaneous hermaphroditism in the marine shrimp Lysmata wurdemanni (Caridea: Hippolytidae): an undescribed sexual system in the decapod Crustacea. Marine Biology 132: 223-235.

BAUER RT \& JH ABDALLA (2000) Patterns of brood production in the grass shrimp Palaemontes pugio (Decapoda: Caridea). Invertebrate Reproduction and Development 38: 107-113.

BAUER RT \& JH ABDALLA (2001) Male mating tactics in the shrimp Palaemontes pugio (Decapoda: Caridea): precopulatory mate guarding vs. pure searching. Ethology 107: 185-199.

BERGLUND A (1981) Sex dimorphism and skewed sex ratios in the prawn species Palaemon adspersus and P. squilla. Oikos 36: 158-162.

BERGSTRÖM BI (1997). Do protandric pandalid shrimp have environmental sex determination? Marine Biology 128: 397-407.

BERGSTRÖM BI (2000). The biology of Pandalus. Advances in Marine Biology 38: 55-245.

BODDEKE R, JR BOSSCHIETER \& PC GOUDSWAARD (1991) Sex change, mating, and sperm transfer in Crangon crangon (L.). In: Bauer RT \& JW Martin (eds) Crustacean sexual biology: 164-182. Columbia University Press, New York, New York, USA.

BOLTAÑA S \& M THIEL (2001) Associations between two species of snapping shrimp Alpheus inca and Alpheopsis chilensis (Decapoda: Caridea: Alpheidae). Journal of the Marine Biological Association of the United Kingdom 81: 633-638.

BOROWSKY B (1983) Reproductive behavior of three tube-building peracarid crustaceans: the amphipods Jassa falcata and Ampithoe valida and the tanid Tanais cavolinii. Marine Biology 77: 257-263.

BOROWSKY B (1985) Differences in reproductive behavior between two male morphs of the amphipod crustacean Jassa falcata Montagu. Physiological Zoology 58: 497-502.

BOUCHARD S, B SAINTE-MARIE \& JN McNEIL (1996) Indirect evidence indicates female semiochemicals release male precopulatory behaviour in the snow crab, Chionocetes opilio (Brachyura: Majidae). Chemoecology 7: 39-44.

CAILLAUX LM \& WB STOTZ (2003) Distribution and abundance of Rhynchocinetes typus Milne Edwards (Crustacea Decapoda), in different benthic community structures in northern Chile. Journal of the Marine Biological Association of the United Kingdom 83: $143-150$.

CALDWELL RL (1991) Variation in reproductive behavior in stomatopod Crustacea. In: Bauer RT \& JW Martin (eds) Crustacean sexual biology: 67-90. Columbia University Press, New York, New York, USA.

CHARNOV EL (1979) Natural selection and sex change in pandalid shrimps: test of life history theory. American Naturalist 113: 715-734. 
CHARNOV EL \& ANDERSON PJ (1989) Sex change and population fluctuations in pandalid shrimp. American Naturalist 134: 824-827.

CHARNOV EL, DW GOTSHALL \& JG ROBINSON (1978) Sex ratio: adaptive response to population fluctuations in pandalid shrimps. Science 200: 204206.

CHRISTY JH (1987) Competitive mating, mate choice and mating associations of brachyuran crabs. Bulletin of Marine Science 41: 177-191.

CHRISTY JH, PRY BACKWELL \& S GOSHIMA (2001) The design and production of sexual signal: hoods and hood building by male fiddler crabs Uca musica . Behaviour 138: 1065-1083.

CLARK RA (1997) Dimorphic males display alternative reproductive strategies in the marine amphipod Jassa marmorata Holmes (Corophioidea: Ischyroceridae). Ethology 103: 531-553.

CLARKE A (1985) The reproductive biology of the polar hippolytid shrimp Chorismus antarcticus at South Georgia. In: Gray JS \& ME Christiansen (eds) Marine biology of polar regions and effects of stress on marine organisms: 237-245. John Wiley \& Sons Ltd., New York, New York, USA.

CONLAN KE (1989) Delayed reproduction and adult dimorphism in males of the amphipod genus Jassa (Corophioidea Ischyroceridae): an explanation for systematic confusion. Journal of Crustacean Biology 9: 601-625.

CORREA C, JA BAEZA, E DUPRÉ, IA HINOJOSA \& M THIEL (2000) Mating behavior and fertilization success of three ontogenetic stages of male rock shrimp Rhynchocinetes typus (Decapoda: Caridea). Journal of Crustacean Biology 20: 628-640.

CORREA C, JA. BAEZA, IA. HINOJOSA \& M THIEL (2003) Male dominance hierarchy and mating tactics in the rock shrimp Rhynchocinetes typus (Decapoda: Caridea). Journal of Crustacean Biology 23: 33-45.

DAMRONGPHOL P, N EANGCHUAN \& B POOLSANGUAN (1991) Spawning cycle and oocyte maturation in the laboratory-maintained giant freshwater prawns (Macrobrachium rosenbergii). Aquaculture 95: 347-357.

DIESEL R (1990) Sperm competition and reproductive success in the decapod Inachus phalangium (Majidae): a male ghost spider crab that seals off rivals' sperm. Journal of Zoology 220: 213-223.

DUFFY JE (1996a) Eusociality in a coral-reef shrimp. Nature 381: 512-514.

DUFFY JE (1996b) Synalpheus regalis, new species, a sponge dwelling shrimp from the Belize barrier reef, with comment on host specificity in Synalpheus. Journal of Crustacean Biology 16: 564-573.

DUFFY JE (1998) On the frequency of eusociality in snapping shrimps (Decapoda: Alpheidae), with description of a second eusocial species. Bulletin of Marine Science 63: 387-400.

DUFFY JE \& KS MACDONALD (1999) Colony structure of the social snapping shrimp Synalpheus filidigitus in Belize. Journal of Crustacean Biology 19: 283292.
DUFFY JE, CL MORRISON \& KS MACDONALD (2002) Colony defense and behavioral differentiation in the eusocial shrimp Synalpheus regalis. Behavioral Ecology and Sociobiology 51: 488-495.

EMLEN ST \& LW ORING (1977) Ecology, sexual selection and the evolution of mating systems. Science 197: 215-223.

FIEDLER GC (1998) Functional, simultaneous hermaphroditism in female-phase Lysmata amboinensis (Decapoda: Caridea: Hippolytidae). Pacific Science 52: 161-169.

GHERARDI F (1991) Eco-ethological aspects of the symbiosis between the shrimp Athanas indicus (Coutière 1903 ) and the sea urchin Echinometra mathaei (de Blainville 1825). Tropical Zoology 4: 107-128.

GHERARDI F \& C CALLONI (1993) Protandrous hermaphroditism in the tropical shrimp Athanas indicus (Caridea), a symbiont of sea urchins. Journal of Crustacean Biology 13: 675-689.

HINOJOSA IA (2001) Habilidad de apareamiento múltiples de los machos y elección criptica de la hembra en el camarón de roca, Rhynchocinetes typus Milne Edwards 1837 (Crustacea: Decapoda: Rhynchocinetidae). Unpublished Thesis, Facultad de Ciencias del Mar, Universidad Católica del Norte, Coquimbo, Chile. 47pp.

HINOJOSA I \& M THIEL (in press) Somatic and gametic resources in male rock shrimp, Rhynchocinetes typus - effect of mating potential and ontogenetic male stage. Animal Behaviour.

HOFFMAN DL (1973) Observed acts of copulation in the protandric shrimp, Pandalus platyceros Brandt (Decapoda, Pandalidae). Crustaceana 24: 241-244.

HUGHES M (1996) The function of concurrent signals: visual and chemical communication in the snapping shrimp. Animal Behaviour 52: 247-257.

IRIBARNE O, M FERNÁNDEZ \& D ARMSTRONG (1996) Mate choice in the amphipod Eogammarus oclairi Bousfield: the role of current velocity, random assortment, habitat heterogeneity and male's behavior. Marine Freshwater Behavioral Physiology 27: 223237.

JIVOFF P (1997) Sexual competition among male blue crab, Callinectes sapidus. Biological Bulletin 193: 368-380.

JIVOFF P \& AH HINES (1998) Female behavior, sexual competition and mate guarding in the blue crab, Callinectes sapidus. Animal Behaviour 55: 589-603.

JORMALAINEN V (1998) Precopulatory mate guarding in crustaceans: male competitive strategy and intersexual conflict. Quarterly Review of Biology 73: 275-304.

KARPLUS I \& S HARPAZ (1990) Preliminary observations on behavioral interactions and distribution patterns of freshwater prawns Macrobrachium rosenbergii under semi-natural conditions (Decapoda: Caridea). Crustaceana 59: 193-203.

KENDALL MS \& TG WOLCOTT (1999) The influence of male mating history on male-male competition and female choice in mating associations in the blue crab, Callinectes sapidus (Rathbun). Journal of Experimental Marine Biology and Ecology 239: 23-32. 
KING MG \& RB MOFFITT (1984) The sexuality of tropical deepwater shrimps (Decapoda: Pandalidae). Journal of Crustacean Biology 4: 567-571.

KNOWLTON N (1980) Sexual selection and dimorphism in two demes of a symbiotic pair-bonding snapping shrimp. Evolution 34: 161-173.

KROPP RK (1987) Descriptions of some endolithic habitats for snapping shrimp (Alpheidae) in Micronesia. Bulletin of Marine Science 41: 204-213.

KURIS A M, Z RA'ANAN, A SAGI \& D COHEN (1987) Morphotypic differentiation of male Malaysian Giant Prawns, Macrobrachium rosenbergii. Journal of Crustacean Biology 7: 219-237.

KVARNEMO C \& I AHNESJÖ (1996) The dynamics of operational sex ratios and competition for mates. Trends in Ecology and Evolution 11: 404-408.

MATHEWS LM (2002a) Tests of the mate-guarding hypothesis for social monogamy: does population density, sex ratio, or female synchrony affect behavior of male snapping shrimp (Alpheus angulatus)? Behavioural Ecology and Sociobiology 51: 426-432.

MATHEWS LM (2002b) Territorial cooperation and social monogamy: factors affecting intrasexual behaviours in pair-living snapping shrimp. Animal Behaviour 63: 767-777.

NAKASHIMA Y (1987) Reproductive strategies in a partially protandrous shrimp, Athanas kominatoensis (Decapoda: Alpheidae): sex change as the best of a bad situation for subordinates. Journal of Ethology 5 : 145-159.

NOLAN BA \& M SALMON (1970) The behavior and ecology of snapping shrimp (Crustacea: Alpheus heterochelis and Alpheus normanni). Forma et Functio 2: 289-335.

OH CW \& RG HARTNOLL (1999) Size at sexual maturity, reproductive output, and seasonal reproduction of Philocheras trispinosus (Decapoda) in Port Erin Bay, Isle of Man. Journal of Crustacean Biology 19: 252-259.

OJEDA FP \& JM FARIÑA (1996) Temporal variations in the abundance, activity, and trophic patterns of the rockfish, Sebastes capensis, off the central Chilean coast. Revista Chilena de Historia Natural 69: 205211.

OMORI K, Y YANAGISAWA \& N HORI (1994) Life history of the caridean shrimp Periclimenes ornatus Bruce associated with a sea anemone in southwest Japan. Journal of Crustacean Biology 14: 132-145.

RA'ANAN Z \& A SAGI (1985) Alternative mating strategies in male morphotypes of the freshwater prawn Macrobrachium rosenbergii (De Man). Biological Bulletin 169: 592-601.

RETAMAL M (2000) Decápodos de Chile. World Biodiversity Database CD-ROM Series.

Associate Editors: Patricio Ojeda and Luis Ebensperger Received October 7, 2002; accepted February 25, 2003
RONDEAU A \& B SAINTE-MARIE (2001) Variable mateguarding time and sperm allocation by male snow crabs (Chionoecetes opilio) in response to sexual competition, and the impact on the mating success of females. Biological Bulletin 201: 204-217.

SEIBT U \& W WICKLER (1979) The biological significance of the pair-bond in the shrimp Hymenocera picta. Zeitschrift für Tierpsychologie 50: 166-179.

SHUSTER SM (1989) Female sexual receptivity associated with molting and differences in copulatory behavior among the three male morphs in Paracerceis sculpta (Crustacea: Isopoda). Biological Bulletin 177: 331-337.

THIEL M \& JA BAEZA (2001) Factors affecting the social behavior of crustaceans living symbiotically with other marine invertebrates: a modeling approach. Symbiosis 30: 163-190.

URBANI N, B SAINTE-MARIE, JS SÉVIGNY, D ZADWORNY \& U KUHNLEIN (1998) Sperm competition and paternity assurance during the first breeding period of female snow crab (Chionoecetes opilio) (Brachyura: Majidae). Canadian Journal of Fisheries and Aquatic Sciences 55: 1104-1113.

VANDENSPIEGEL D, I EECKHAUT \& M JANGOUX (1998) Host selection by Synalpheus stimpsoni (De Man), an ectosymbiotic shrimp of comatulid crinoids, inferred by a field survey and laboratory experiments. Journal of Experimental Marine Biology and Ecology 225: 185-196.

WADA S, M ASHIDATE \& S GOSHIMA (1997) Observations on the reproductive behavior of the spiny king crab Paralithodes brevipes (Anomura: Lithodidae). Crustacean Research 26: 56-61.

WAHLE RA (1992) Body-size-dependent anti-predator mechanisms of the American lobster and a model of their trade-offs. Oikos 65: 52-60.

WARNER RR (1975) The adaptive significance of sequential hermaphroditism in animals. American Naturalist 109: 61-82.

WARNER RR (2001) Synthesis: environment, mating systems, and life history allocations in the bluehead wrasse. In: Dugatkin LA (ed) Model systems in behavioral ecology: integrating conceptual, theoretical, and empirical approaches: 227-244. Princeton University Press, Princeton, New Jersey, USA.

WICKLER W (1973) Biology of Hymenocera picta Dana. Micronesia 9: 225-230.

WIRTZ P \& R DIESEL (1983) The social structure of Inachus phalangium, a spider crab associated with the sea anemone Anemonia sulcata. Zeitschrift für Tierpsychologie 62: 209-234.

ZHANG D, J LIN \& RL CRESWELL (1998) Mating behavior and spawning of the banded coral shrimp Stenopus hispidus in the laboratory. Journal of Crustacean Biology 18: 511-518. 


\section{APPENDIX 1}

Probable mating system of 30 caridean species and their sexual system and sexual dimorphism of body size and/or major chelae size; * indicates group with particular yet insufficiently

known mating system (see text); empty spaces are left where no information is available; (Gc) $=$ gonochoristic $;(\mathrm{H})=$ hermaphroditic $;(\mathrm{P})=$ protandric $;(\mathrm{Pa})=$ partial $;(\mathrm{S})=$ simultaneous with cross fertilization; $(\mathrm{M})=$ male; $(\mathrm{F})=$ female; $(\mathrm{M})$ or $(\mathrm{F})=$ sex of proportion of population that does not change sex, male and female respectively

Probable sistema de apareamiento de 30 especies de carideos y sus respectivos sistemas sexuales y dimorfismos sexuales de tamaño corporal y/o del tamaño de quela mayor; * indica un grupo con un sistema de apareamiento particular pero aun insuficientemente conocido (ver texto); se dejaron espacios vacíos donde no hay información

disponible; $(\mathrm{Gc})=$ gonocórico $;(\mathrm{H})=$ hermafrodita $;(\mathrm{P})=$ protándrico; $(\mathrm{Pa})=$ parcial; $(\mathrm{S})=$ simultaneo con fecundación cruzada $(\mathrm{M})=\operatorname{macho} ;(\mathrm{F})=$ hembra; $(\mathrm{M})$ o $(\mathrm{F})=$ sexo de la porción de la población que no cambia de sexo, machos y hembras, respectivamente

\begin{tabular}{clll}
\hline $\begin{array}{c}\text { Mating system } \\
\text { Taxon }\end{array}$ & $\begin{array}{l}\text { Sexual } \\
\text { system }\end{array}$ & $\begin{array}{l}\text { Sexual dimorphism } \\
\text { (in body size or major chelae size) }\end{array}$ & Reference \\
\hline
\end{tabular}

(*) Eusociality

Alpheidae

Synalpheus chacei
S. filidigitus

S. regalis

(i) Monogamy

Alpheidae

Alpheopsis chilensis

Alpheus angulatus

A. armatus

A. heterochaelis

A. idiocheles

A. inca

A. normanni

Synalpheus stimpsoni

Gnathophyllidae

Hymenocera picta

Hippolytidae

Lysmata amboinensis
L. grabhami

Palaemonidae

Periclimenes ornatus

(ii) Neighborhoods of Dominance

Palaemonidae

Rhynchocinetidae

Rhynchocinetes typus

(iii) Pure Searching

Crangonidae

Crangon crangon

Hippolytidae

Heptacarpus paludicola

H. pictus

Lysmata wurdemanni

Thor manningi

Palaemonidae

Palaemontes pugio

Palaemon squilla

Pandalidae

Pandalus borealis

$P$. hypsinotus

P. latirostris

P. platyceros

$\begin{array}{ll}\text { Gc ? } & \begin{array}{l}\text { size M } \sim \mathrm{F} \\ \text { chelae F substantially }<\mathrm{M} \\ \text { chelae F slightly }<\mathrm{M}\end{array} \\ \mathrm{Gc} ? & \begin{array}{l}\text { size } \mathrm{M} \sim \mathrm{F} \\ \text { size } \mathrm{M} \sim \mathrm{F}\end{array} \\ \mathrm{Gc} ? & \\ \mathrm{Gc} ? & \\ & \\ \text { PSH } & \\ \text { PSH } & \end{array}$

size $\mathrm{M}<\mathrm{F}$; chela $\mathrm{F}<\mathrm{M}$

Gc

size $\mathrm{F}<\mathrm{M}$; chela $\mathrm{F}<\mathrm{M}$

size $\mathrm{F}<\mathrm{M}$; chela $\mathrm{F}<\mathrm{M}$

$\mathrm{PaPH}(\mathrm{F}) \quad$ size $\mathrm{M}$ phase $<\mathrm{F}$ phase $\sim(\mathrm{F})$

size $\mathrm{M}<\mathrm{F}$

Gc $\quad$ size $\mathrm{M}<\mathrm{F}$

$\mathrm{PSH} \quad$ size $\mathrm{M}$ phase $<\mathrm{F}$ phase $(\mathrm{SH})$

$\mathrm{PaPH}(\mathrm{F}, \mathrm{M}) \quad$ size $\mathrm{M}$ phase $\sim(\mathrm{M})<\mathrm{F}$ phase $\sim(\mathrm{F})$

Gc

size $\mathrm{M}<\mathrm{F}$

size $\mathrm{M}<\mathrm{F}$

$\mathrm{PaPH}(\mathrm{F})$

$\mathrm{PaPH}(\mathrm{M})$

size $\mathrm{M}$ phase < $\mathrm{F}$ phase, $(\mathrm{F})$

size $\mathrm{M}$ phase < F phase, ? (M)

$\mathrm{PH}$

$\mathrm{PH}$

size $\mathrm{M}$ phase $<\mathrm{F}$ phase

size $\mathrm{M}$ phase $<\mathrm{F}$ phase
Duffy (1998)

Duffy \& Macdonald (1999)

Duffy (1996a, 1996b),

Duffy et al. (2002)

Boltaña \& Thiel (2001)

Mathews (2002a, 2002b)

Knowlton (1980)

Nolan \& Salmon (1970)

Kropp (1987)

Boltaña \& Thiel (2001)

Bauer (1989), Nolan \& Salmon (1970)

Vanden-Spiegel et al. (1998)

Wickler (1973),

Seibt \& Wickler (1979)

Fiedler (1998)

Wirtz (1997 in Bauer 2000)

Omori et al. (1994)

Ra' anan \& Sagi (1985),

Kuris et al. (1987)

Correa et al. (2003)

Boddeke et al. (1991)

Bauer (1979 in Bauer 1986b)

Bauer (1976)

Bauer \& Holt (1998)

Bauer (1986b)

Bauer \& VanHoy (1996)

Bauer \& Abdalla (2001)

Berglund (1981)

Charnov (1979), Bergström (1997)

Kurata (1981), Butler (1980), both in Bergström (2000)

Mizushima \& Omi (1979) and Kurata 1981), both in Bergström (2000)

Butler (1964, 1980 in Bauer 2000),

Hoffman (1973)

Gherardi (1991),

Gherardi \& Calloni (1993)

Nakashima (1987)

Please note that for some species the mating system is known but no information on sexual system or sexual dimorphism is available 